Gut, 1978, 19, 273-276

\title{
Absence of $\mathrm{K}$ cells in human gut mucosa
}

\author{
R. CLANCY ${ }^{1}$ AND ALESSANDRA PUCCI
}

From the Department of Clinical Immunology, Royal Prince Alfred Hospital, Sydney, Australia

SUMMARY Lymphocytes have been isolated from human rectal biopsies in numbers sufficient for microassay procedures. No antibody-dependent cell-mediated cytotoxic (ADCC) activity could be detected in normal or inflamed human gut mucosa, using two assay systems which detect predominantly $\mathrm{K}$ cell activity. The tissue localisation and circulation characteristics of $\mathrm{K}$ cells require definition before establishing their role as an efferent immunological mechanism.

Target cell 'kill' by antibody-dependent cell-mediated cytotoxicity (ADCC) is an appealing mechanism for mediating both local resistance in health and mucosal damage in disease. In vitro studies using cells obtained from peripheral blood suggest that ADCC may contribute to tissue damage in inflammatory disease of both the small and large bowel (Fakhri and Hobbs, 1972; Shorter, 1974). The immunological potential of the gut mucosa, however, is restricted to those mechanisms which the local apparatus can support, or which can be recruited into the gut mucosa. We describe an absence of ADCC with cells obtained from both normal and inflamed colonic mucosa.

\section{Methods}

Specimens of human gut were obtained following resection, or by rectal biopsy forceps. Rectal biopsies weighed between 22 to $40 \mathrm{mg}$. Histological diagnosis was made in each subject. A single cell suspension was made from either the entire rectal biopsy or a piece of mucosa-submucosa dissected from resected gut, measuring about $2.5 \mathrm{~cm}^{2}$ (1 square inch). The gut mucosa was washed twice in phosphate buffered saline (PBS) containing gentamicin $(50 \mu \mathrm{g} / \mathrm{ml})$ and finely minced with scissors. The fragments were ground on a sieve (300 mesh) and cells washed through with RPMI 1640 medium containing $5 \%$ foetal calf serum, from a pasteur pipette. The cell suspension was passed through a siliconised glass bead column. For rectal biopsies, a $10 \mathrm{ml}$ syringe with a 19 gauge needle was packed from the bottom with $1 \mathrm{~cm}$ of $3 \mathrm{~mm}$ beads, $1 \mathrm{~cm}$ of $1 \mathrm{~mm}$ beads, and $4 \mathrm{~cm}$ of $3 \mathrm{~mm}$ beads. For resected

1 Present address: Faculty of Medicine, University of Newcastle, NSW, Australia.

Received for publication 2 November 1977 gut, a $50 \mathrm{ml}$ syringe was packed in similar fashion.

The final cell suspension consisted of more than $90 \%$ lymphocytes. Cell recovery from the rectal biopsies was 400000 to 800000 , while about $5-10 \times 10^{6}$ cells per $2.5 \mathrm{~cm}^{2}$ of resected mucosa were obtained. Cell viability was confirmed by mitotic response to pokeweed mitogen and trypan blue exclusion by cultured cells.

Two assays for ADCC were used. In the first the Chang hepatoma cell assay (Hersey et al., 1976) was used with rabbit anti-Chang cell antibody. Rabbit antibody was used at optimal dilution. ADCC was detected as specific release of $\mathrm{Cr}^{51}$ from labelled target cells according to the formula:

$$
\frac{a-b}{c-b} \times 100
$$

where $\mathrm{a}=$ loss of $\mathrm{Cr}^{51}$ from Chang cells in presence of anti-Chang cell antibody (1/100); $b=$ spontaneous loss of $\mathrm{Cr}^{51}$ from Chang cells; $\mathrm{c}=$ maximum releasable $\mathrm{Cr}^{51}$ from Chang cells (in distilled water).

The second assay used Chang cells labelled with $\mathrm{Cr}^{51}$ as above and coated with $E$. coli lipopolysaccharide prepared by boiling cultures of six $E$. coli strains (the most common Australian serotypes obtained from Institute of Medical and Veterinary Science, Adelaide). Chang cells were coated by incubating $1 \times 10^{6}$ Chang cells in $4 \mathrm{ml}$ supernatant (Neter, 1956). Pooled sera from six normal subjects shown to have agglutinating activity against the $E$. coli lipopolysaccharide by haemagglutination were used in the ADCC assay at an optimal dilution, determined from a dose response curve using peripheral blood lymphocytes. Results were obtained according to the above formula. Incubation in each assay was for 18 hours at $37^{\circ} \mathrm{C}$. Consideration of the variation in these systems indicated specific cytotoxicity when more than $5 \%$ 
$\mathrm{Cr}^{51}$ release was detected.

Circulating lymphocytes were obtained from blood taken into heparin $(10 \mu / \mathrm{ml})$ at the time of biopsy or resection. Lymphocytes were isolated by centrifugation over Ficoll-Hypaque (Boyum, 1968). Lymphocytes treated with proteolytic enzyme were incubated with trypsin $(2 \mathrm{mg} / \mathrm{ml})$ at $37^{\circ} \mathrm{C}$ for 30 minutes, and washed with RPMI 1640 medium containing $15 \%$ AB serum. Trypsin was obtained from bovine pancreas and twice crystallised (Sigma).

\section{Results}

ADCC activity was regularly demonstrated in blood lymphocytes with both assays (Tables 1 and 2). Processing of blood lymphocytes by the technique used to isolate gut lymphocytes caused no loss of ADCC activity.

The spontaneous rate of $\mathrm{Cr}^{51}$ loss from Chang cells was $28-32 \%$ over 18 hours and addition of blood or gut lymphocytes in the ratios expressed in Tables 1 and 2, in the absence of antibody, increased $\mathrm{Cr}^{51}$ loss by less than $5 \%$. Addition of $E$. coli antigen to the Chang cell surface, however, increased the rate of 'spontaneous' loss of $\mathrm{Cr}^{51}$ in the absence of lymphocytes to $35-40 \%$ over 18 hours. With mucosal lymphocytes ADCC activity was not detected regardless of whether human or rabbit antibody was used, or whether lymphocytes were obtained from normal or inflamed gut.

The possibility that $\mathrm{K}$ cell activity was masked by adsorbed blocking factors was examined by preincubation of gut lymphocytes, and treatment with proteolytic enzyme trypsin (Table 3). In neither case could significant $\mathrm{K}$ cell activity be detected. The loss of $\mathrm{K}$ cell activity in blood after 24 hours suggests that $\mathrm{K}$ cells may have a short lifespan in culture.

Table 3 Failure of incubation and trypsin digestion to enhance $A D C C$

\begin{tabular}{llll}
\hline Cell source & Specific cytotoxicity $(\%)$ & $\begin{array}{l}\text { Post trypsin } \\
\text { digestion }\end{array}$ \\
\cline { 2 - 4 } & Preincubation & $\begin{array}{l}24 \mathrm{~h} \text { incubation } \\
\text { at } 37^{\circ} \mathrm{C}\end{array}$ & \\
\hline Colon & $1 \cdot 5$ & 0 & 0 \\
Blood & 12 & 0 & 8 \\
Colon & - & 3 & - \\
Blood & - & 7 & - \\
\hline
\end{tabular}

Lymphocytes obtained from normal descending colon and blood of two patients with carcinoma of sigmoid colon. Lymphocyte/target cell ratio $25 / 1$.

\section{Discussion}

The 'homing' of cells mediating ADCC is determined

Table 1 Antibody-dependent cell-mediated cytotoxicity in human gut mucosa*

\begin{tabular}{|c|c|c|c|c|}
\hline \multirow[t]{2}{*}{ Diagnosis (treatment) } & \multirow{2}{*}{$\begin{array}{l}\text { Source of gut } \\
\text { lymphocytes }\end{array}$} & \multirow{2}{*}{$\begin{array}{l}\text { Lymphocyte/target } \\
\text { cell }\end{array}$} & \multicolumn{2}{|c|}{ Specific cytotoxicity $(\%)$} \\
\hline & & & Blood lymphocytes & Gut lymphocytes \\
\hline $\begin{array}{l}\text { Normal } \\
\text { Normal } \\
\text { Ulcerative colitis } \\
\text { Ulcerative colitis (steroids) } \\
\text { Ulcerative colitis (salazopyrin) } \\
\text { Crohn's disease (steroids) } \\
\text { Ulcerative colitis (steroids) }\end{array}$ & $\begin{array}{l}\text { Rectum (biopsy) } \\
\text { Rectum (biopsy) } \\
\text { Rectum (biopsy) } \\
\text { Rectum (biopsy) } \\
\text { Rectum (biopsy) } \\
\text { Asc. colon (colectomy) } \\
\text { Asc. colon (colectomy) }\end{array}$ & $\begin{array}{l}20 / 1 \\
17 / 1 \\
10 / 1 \\
15 / 1 \\
10 / 1 \\
10 / 1 \\
20 / 1 \\
50 / 1 \\
10 / 1 \\
20 / 1 \\
50 / 1\end{array}$ & $\begin{array}{r}67 \\
30 \\
12 \\
33 \\
10 \\
23 \\
34 \\
45 \\
1 \\
3 \\
3\end{array}$ & $\begin{array}{l}0 \\
0 \\
0 \\
0 \\
0 \\
0 \\
0 \\
0 \\
1 \\
0 \\
1\end{array}$ \\
\hline
\end{tabular}

*Target cell is Chang cell; antibody is rabbit anti-Chang cell serum at dilution of 1:100.

Table 2 Antibody-dependent cell-mediated cytotoxicity in human gut mucosa*

\begin{tabular}{|c|c|c|c|c|}
\hline \multirow[t]{2}{*}{ Diagnosis (treatment) } & \multirow{2}{*}{$\begin{array}{l}\text { Source of gut } \\
\text { lymphocytes }\end{array}$} & \multirow{2}{*}{$\begin{array}{l}\text { Lymphocyte/target } \\
\text { cell }\end{array}$} & \multicolumn{2}{|c|}{ Specific cytotoxicity (\%) } \\
\hline & & & Blood lymphocytes & Gut lymphocytes \\
\hline Crohn's disease (steroids) & $\begin{array}{l}\text { Asc. colon } \\
\text { (colectomy) }\end{array}$ & $\begin{array}{r}50 / 1 \\
100 / 1\end{array}$ & 10 & $\begin{array}{l}\mathbf{0} \\
\mathbf{0}\end{array}$ \\
\hline Carcinoma colon & $\begin{array}{l}\text { Terminal ileum } \\
\text { (R hemicolectomy) }\end{array}$ & $100 / 1$ & 18 & 0 \\
\hline Carcinoma colon & $\begin{array}{l}\text { Desc. colon } \\
\text { (L hemicolectomy) }\end{array}$ & $100 / 1$ & 23 & 0 \\
\hline
\end{tabular}

* Target cell is Chang cell coated with $E$. coli antigen; antibody is pooled normal serum at 1:100 dilution. Gut mucosa was histologically normal. 
by their capacity to bind to Fc fragments of antibody bound to target cells (MacLennan, 1976). This provides a sensitive and economical mechanism for target cell destruction. In vitro evidence suggests that ADCC may contribute to host resistance to infection (Simone et al., 1972) and to tissue destruction in certain autoimmune diseases (Calder et al., 1973), but clear demonstration of an in vivo effect is lacking.

It is important, therefore, that cells capable of mediating ADCC could not be isolated from histologically normal or inflamed human colon mucosa. Parallel studies of peripheral blood lymphocytes regularly demonstrated ADCC. E. coli antigen was adsorbed to Chang cells and tested as antigen in ADCC with human antibody specifically to examine the hypothesis that the pathogenesis of ulcerative colitis may include ADCC, involving mucosal $\mathrm{K}$ cells and antibody to colon epithelial cells, which crossreacts with antigens common to a number of enterobacterial species (Shorter, 1974). Again, no $\mathrm{K}$ cell activity could be detected. The apparent intravascular restriction of $K$ cells emphasises the importance of determining the distribution and circulation characteristics of these cells in man before an effector role can be attributed to them. Absence of such cells from thoracic duct lymph (Holm et al., 1974), mouse Peyer's patches (Nelson et al., 1976), and guinea-pig lung (Hunninghake and Fauci, 1976) indicates a general depletion of this cell population in mucosal lymphoid tissue. The possibility that $\mathrm{K}$ cells were present, but that their activity was masked by adsorbed factors, was considered unlikely when incubation at $37^{\circ} \mathrm{C}$ for 24 hours and treatment with proteolytic enzyme was not followed by the appearance of ADCC. Indeed, ADCC may be undesirable in the gut mucosa as the local immune response to gut contents includes antibody which crossreacts with host antigen, which in the presence of ADCC may induce mucosal damage.

Effector cells vary in different antibody sensitised target cell systems. Chang cell lysis reflects predominantly $\mathrm{K}$ cell activity, while monocytes, $\mathrm{B}$ cells, and neutrophils mediate lysis of other antibodysensitised target cells (Holm, 1972; Chess et al., 1974; Kovithavongs et al., 1975). K cells have the appearance of lymphocytes, but lack the unique surface markers of T or B cells (MacLennan, 1976). It can be stated, therefore, that few $K$ cells are present within normal colon mucosa, nor can they be recruited through inflammation. While $K$ cells probably do not contribute to the pathogenesis of inflammatory bowel disease, a contribution by other ADCC mechanisms can not be excluded.

These studies of gut lymphocyte function followed the development of a simple procedure for isolating lymphocytes from rectal biopsies in numbers sufficient for microassay procedures. This method overcame the problem of cell trapping in mucus and provided a lymphocyte population free from significant contamination with epithelial cells and debris. It may be expected that the direct study of the cellular basis of mucosal defence mechanisms and the pathogenesis of mucosal disease in man may be facilitated by the use of this technique.

We thank Dr N. Gallagher, Dr D. Glenn, Dr S. Goulston, Dr R. Kater, Dr B. Morgan, and Dr K. Perkins, for providing specimens and $\mathrm{Sr}$ NicollWilson for her invaluable help, and the Ramaciotti Foundation for their generous support.

\section{References}

Boyum, A. (1968). Isolation of leukocytes from human blood. Further observations. Methylcellulose, dextran, and ficoll as erythrocyte aggregating agents. Scandinavian Journal of Clinical and Laboratory Investigation, 21, suppl. 97, 31-50.

Calder, E. A., Penhale, W. J., Barnes, E. W., and Irvine, W. J. (1973). Cytotoxic lymphocytes in Hashimoto thyroiditis. Clinical and Experimental Immunology, 14, 19-23.

Chess, L., McDermott, R. P., Sondel, P. M., and Scholossman, S. F. (1974). Population of cells involved in human cellular hypersensitivity. In Progress in Immunology II, vol. 3, pp. 125-132. Edited by L. Brent and J. Holborow. North-Holland: Amsterdam.

Fakhri, O., and Hobbs, J. R. (1972). Detection of antibodies which can cooperate with lymphocytes. Lancet, 2 , 403-406.

Hersey, P., Edwards, S., and Edwards, J. (1976). Characterization of mononuclear effector cells in human blood. Clinical and Experimental Immunology, 23, 104-113.

Holm, G. (1972). Lysis of antibody-treated human erythrocytes by human leukocytes and macrophages in tissue culture. International Archives of Allergy and Applied Immunology, 43, 671-682.

Holm, G., Franksson, C., Campbell, A. C., and MacLennan, I. C. M. (1974). The cytotoxic activity of lymphocytes from human lymph in vitro. Clinical and Experimental Immunology, 17, 361-369.

Hunninghake, G. W., and Fauci, A. S. (1976). Immunologic reactivity of the lung. II. Cytotoxic effector function of pulmonary mononuclear cell subpopulations. Cellular Immunology, 26, 98-104.

Kovithavongs, T., Rice, G., Thong, K. L., and Dossetor, J. B. (1975). Effector cell activity in antibody mediated cell dependent immune lysis. II. Evidence for different populations of effector cells for different targets. Cellular Immunology, 18, 167-175.

MacLennan, I. C. M. (1976). Function and evaluation of human K-cells. Clinical Tumor Immunology, pp. 47-53. Edited by J. Wybran and M. J. Staquet. Pergamon Press: Oxford.

Nelson, D. L., Bundy, B. M., Blaese, R. M., and Strober, W. (1976). Cytotoxic effector cell function in organised gutassociated lymphoid tissue (GALT). Cellular Immunology. 22, 165-175.

Neter, E. (1956). Bacterial hemagglutination and hemolysis. 
Bacteriological Reviews, 20, 166-188.

Shorter, R. G. (1974). Immunological aspects of gastrointestinal disease; an up-to-date account of inflammatory diseases such as ulcerative colitis and Crohn's disease. In Progress in Immunology II, vol. 4, pp. 209-219.
Edited by L. Brent and J. Holborow. North-Holland: Amsterdam.

Simone, J. V., Holland, E., and Johnson, W. (1972). Fatalities during remission of childhood leukaemia. Blood, 39, 759-770. 